Relations industrielles

Industrial Relations

\title{
Gary N. CHAISON : When Union Merge. Lexington, Lexington Books, 1986, 186 pp., ISBN 0-669-11081-7
}

\section{P. Andiappan}

Volume 42, numéro 3, 1987

URI : https://id.erudit.org/iderudit/050344ar

DOI : https://doi.org/10.7202/050344ar

Aller au sommaire du numéro

Éditeur(s)

Département des relations industrielles de l'Université Laval

ISSN

0034-379X (imprimé)

1703-8138 (numérique)

Découvrir la revue

Citer ce compte rendu

Andiappan, P. (1987). Compte rendu de [Gary N. CHAISON : When Union Merge. Lexington, Lexington Books, 1986, 186 pp., ISBN 0-669-11081-7]. Relations industrielles / Industrial Relations, 42(3), 649-651.

https://doi.org/10.7202/050344ar

Tous droits réservés (C) Département des relations industrielles de l'Université Laval, 1987
Ce document est protégé par la loi sur le droit d'auteur. L’utilisation des services d'Érudit (y compris la reproduction) est assujettie à sa politique d'utilisation que vous pouvez consulter en ligne.

https://apropos.erudit.org/fr/usagers/politique-dutilisation/ 
When Union Merge, by Gary N. Chaison, Lexington Books, Lexington, Massachusetts, 1986, 186 pp., ISBN 0-669-11081-7

This book and the research on which it is based represents a significant contribution to the systematic study of union mergers. The author, Professor Gary Chaison, has attempted to unify and extend the research he has conducted on union mergers over the past fifteen years. Based on the contents of the book, one would not hesitate to observe that Chaison succeeds admirably in this attempt.

Studies on union mergers have used different approaches. The case study method in which one or a few instances of mergers are investigated in detail is often found lacking because of its questionable generalizability. Empirical studies attempt to uncover statistically significant relationships between frequency or types of mergers as well as measures of economic and union conditions. But they fail to consider diverse motives of union mergers as well as the political nature of the merger barriers. A third way of looking at mergers has been through "Chronologies» which use factual information on union mergers in a specific time period. Such periodic studies carried out by U.S. Bureau of Labor Statistics often do not disciss merger negotiations or unsuccessful merger attempts or provide a comprehensive theory that explains and links mergers in different time periods. Realizing the limitations, the author attempts to integrate these various studies into a general model that tells us why and how unions merge as well as the outcomes of this process. Chaison views mergers from the perspective of systems theory which enables him to stand back and conceptualise the major components of union mergers and then examine in detail each component and its interconnections with other parts of union structure and administration. Chaison's model of the union merger process, which serves as the basis for the organization of this book, shows that when motivation to merge is greater than the barriers to merge, it leads to merger negotiations which could end in approval of merger agreement by union officers and members. In the post merger period, governing structures of merged union develop and merger outcomes are evaluated.

Chaison provides a historical overview of 183 National Union mergers in the U.S. during the years 1890-1984. He identifies 47 amalgamations - «fusion of two or more unions to form a new union» and 136 absorptions - «the merging of one union into another». He uses this rich historical information to identify motivating factors to merge. Membership declines and financial hardship are only symptoms of motivating factors. Chaison concludes that the desire to amalgamate or be absorbed can be the result of technological change, narrow or overlapping jurisdictions, a lack of economies of scale in union operations, the need to increase bargaining power, employer merger, reorganization and diversification and the need for protection against raids. Union alliances are seen as preludes to or alternatives to mergers.

Whether or not a union will merge is determined by the countervailing forces of motivations and barriers to merger and the extent to which these forces are reduced or redirected by union alliances. Leadership opposition is usually the earliest barrier and often the most formidable one. Union officers oppose a merger because of combinations of personal, political and financial reasons. Though the author has devoted some attention towards the role of the union leaders in mergers, a more detailed and vivid discussion of the personality characteristics of union leaders and the impact of these characteristics on success or failure of mergers would have been useful. Even if officers favour the merger in principle, members may oppose it because of attachment to the current union or a fear of submergence in the merged union. Also when other unions or a fedeiation opposes the merger, merger efforts could fail. As Chaison points out, these barriers to merger should be measured in relation to motivation to merge. Two or more unions will agree to merge when the strength of each union's motivating forces is sufficient to overcome the barriers that it faces. The compromises found in the merger 
agreements are shaped by the forces acting for and against merger and can call for varying degrees of integration of governing structures in the postmerger union.

Studies of union mergers seldom address the question of whether or not the merger produced the intended results. The merger outcomes are often stated in vague terms. Chaison's study makes a major contribution in this respect by providing a systematic analysis of the links between premerger conditions and postmerger states. He identified twelve merger outcomes, some of which correspond to the motivating factors mentioned earlier. Several conclusions on the merger outcomes are interesting to observe. In any individual merger case, there may be increased bargaining power and an enhanced ability to strike but that these are probably not outcomes which are shared by any significant number of merged unions. Too many other forces shape bargaining power and strike ability. Chaison also finds that effectiveness of merger as a means to protect against raids has apparently encouraged raids as a means to intensify union's motivation to merge. Union officers often claim that merger will enable the union to organize more effectively but Chaison finds that this outcome is far from common. On the other hand, mergers have helped by reducing jurisdictional disputes (if they were the prime motivating force for merger) and by increasing staff expertise and experience for the absorbed union. Chaison also notes that merger outcomes are often interrelated and frequently shaped by the degree of integration of union governing structures.

For the Canadian readers, the chapter on Comparative View of Union Mergers which appraises the relevancy of Chaison's model to union mergers in Great Britain and Canada should be of great interest. Chaison finds that two key characteristics of Canadian unions - fragmentation (multiunionism) and international unionism - have strongly affected the patterns of past merger activity and the potential for future mergers. Thirty eight of the 55 mergers which occured in Canada during the years 1956 to 1984 were either among international unions or between Canadian national unions and international unions. Consequently, the motivation and barriers to merge in Canada are primarily a reflection of merger activity in the U.S. International unions opposed the mergers negotiated independantly by their Canadian sections and Canadian sections created barriers to the mergers of international unions. The neverending controversy over the intentions and effectiveness of international unions have also created an important merger barrier, preventing Canadian national unions from merging with international unions. Canadianisation of the unions, which has been gaining momentum since the early 1970 s, is expected to open up new merger possibilities as Canadian sections gain the right to merge without the permission of their parent unions. Chaison predicts that the merger movement and the broader Canadianisation movement will intensify each other and widen the gulf between the two North American labour movements.

Chaison also makes certain predictions about the shape of mergers in the next ten years in the U.S. Given the poor health of unions in the U.S., he expects that more and more smaller unions will be attracted to absorption as a means for continued survival even if it entails survival as part of another union. Many larger unions, being unable or unwilling to invest the needed financial resources and personnel for large scale campaigns, will find it much faster and less expensive to «organize unions» building from the top down through a series of absorptions rather than organising individual employees. The author also envisions the emergence of some new general unions claiming the right to represent all workers in all industries and conglomarate unions wanting to represent employees in related industries. Chaison anticipates that difficulty in recruiting new members, the abandonment of traditional jurisdictions and increased reliance on absorptions for union growth may frequently result in mergers that could be considered predatory. Chaison advises that some vulnerable unions may have to resort to a «friendly» absorption to protect against an «unfriendly» one - a variation of a strategy used in corporate mergers. 
Overall, this book presents a comprehensive theory of union mergers that is capable of explaining the forces acting for and against mergers, as well as the characteristics of, and links between the pre- and postmerger states. It is thought-provoking and carefully researched. It is a valuable resource for researchers and students interested in unions in North America. Chaison's lucid and rich writing style makes it interesting to read about the complex process of union mergers.

Till now, there was no unifying or comprehensive theory of union merger process despite the recognition of the past and future importance of union mergers. Chaison's book fills this void by providing a model with ability to explain more than the contemporary mergers. It is the most definitive work on union mergers and I recommend it to any scholar interested in the study of unions.

P. ANDIAPPAN

University of Windsor

Freedom of Association and Industrial Relations, by F. von Prondzynski, London, Mansell Publishing Limited, 1987, 248 pp., ISBN 0-7201-1775-5

Le législateur et le juge oscillent, selon les pays et les époques, entre deux grandes conceptions de la liberté syndicale: d'une part, dans une perspective politico-libérale, la faculté de l'individu de s'associer ou de s'abstenir de le faire, faculté qui ne souffre que quelques exceptions, en raison, notamment, de la sécurité publique; de l'autre, une notion «fonctionnelle» ou téléologique du recours à l'action syndicale; on l'assure alors en tant que moyen d'atteindre un certain ordre social, plus spécifiquement, un équilibre du pouvoir de négociation entre employeurs et salariés. Moins nette que la première, cette seconde notion n'est pas moins importante; elle exprime les préalables économiques d'une liberté significative et touche ainsi à la répartition du pouvoir dans la société.

L'objet de l'auteur est d'établir dans quelle mesure l'ordre juridique de certains pays reflète l'une ou l'autre de ces conceptions de la liberté syndicale. La préoccupation vise primordialement le Royaume-uni (a l'exclusion de l'Irlande du Nord) et la République d'Irlande, mais elle conduit aussi à des comparaisons avec la situation en République fédérale allemande, de même qu'aux États-Unis. Si les pages sur lesquelles se referme le livre dénoncent le retrait qu'opèrent les interventions législatives des récentes années du gouvernement de madame Thatcher dans le domaine des relations du travail par rapport à cette seconde conception fonctionnelle de la liberté syndicale, l'ensemble de l'ouvrage envisage le sujet avec le recul historique nécessaire. L'auteur, présentement lecturer en relations industrielles à Trinity College, Dublin s'appuie en partie sur une précédente thèse de doctorat.

Indépendamment de la dizaine de chapitres qui le composent, l'ouvrage paraît comporter essentiellement deux plans. La première moitié, qui regroupe les six premiers chapitres, présente une analyse générale de la liberté syndicale. D'abord, quelques pages distinguent, dans le sillage du juriste américain Hohfeld, le concept de droit de celui de liberté. En fait, l'intervention législative, qui protège la liberté d'association à l'endroit de tiers, crée autant de «droits», au-delà de la simple permissivité étatique à la quelle se réduirait autrement la liberté d'association. Cet exposé initial précède une brève typologie des grands modes de régulation de l'action syndicale dans les pays en cause. Jusqu'où en définitive, un état peut-il favoriser certains syndicats, en leur conférant par exemple, un monopole de représentation, comme aux Etats- 